\title{
Brittle reactivation of ductile shear zones in Brazilian Equatorial Margin
}

Aline Cristine Tavares ${ }^{1}$, David Lopes de Castro ${ }^{1}$, Ole Rønø Clausen², Diógenes Custódio de Oliveira ${ }^{1}$, Francisco Hilario R. Bezerra $^{1}$, Helenice Vital ${ }^{1}$

${ }^{1}$ Universidade Federal do Rio Grande do Norte - Brazil, ${ }^{2}$ Aarhus University - Denmark

Copyright 2021, SBGf - Sociedade Brasileira de Geofísica.

This paper was prepared for presentation during the $17^{\text {th }}$ International Congress of the Brazilian Geophysical Society held in Rio de Janeiro, Brazil, 16-19 August 2021. Contents of this paper were reviewed by the Technical Committee of the $17^{\text {th }}$ International Congress of the Brazilian Geophysical Society and do not necessarily represent any position of the SBGf, its officers or members. Electronic reproduction or storage of any part of this paper for commercial purposes without the written consent of the Brazilian Geophysical Society is prohibited.

\begin{abstract}
We analyze an onshore and offshore area in Brazilian Equatorial Margin using magnetic and reflection seismic data associated with previous geological and geophysical data to investigate the brittle reactivation of ductile shear zones and their role in the evolution of the Ceará basin.
\end{abstract}

The Pangea breakup caused the separation of the South American and African continents about 110 Ma. With the formation of the Atlantic Ocean, the evolution of the Brazilian Equatorial Margin resulted in divergent and transform segments induced by large oceanic fracture zones, such as Saint Paul and Romanche. The brittle reactivation of shear zones and their role in the evolution of the margin and their sedimentary basins in passive continental margins are still debated. This study investigates the reactivation of ductile Precambrian shear zones and their role in the Brazilian Equatorial Margin evolution during the formation of the Equatorial Atlantic in an area influenced by the Romanche Fracture Zone. The study area encompasses the Ceará Basin, the crystalline basement (Borborema Province), and continental-scale structures such as the Transbrasiliano Lineament. We combined and interpreted a set of satellite, airborne and marine magnetic data and reflection seismic associated with previous geological and geophysical data to reach our aim. The magnetic maps generated allowed us to divide the Borborema Province into different magnetic domains bounded by the main shear zones. Our preliminary results indicate that the magnetic lineaments mark the main shear zones in the crystalline basement and the continuity of these lineaments underneath the Ceará Basin. In the sedimentary basins, the magnetic lineaments are consistent with flower structures observed in the seismic interpretations. These structures express the brittle reactivation of the shear zones both in the rift and post-rift sequences. 